\title{
Udział Stanisława Tomkowicza w restauracji kolegiaty Bożego Ciała w Bieczu
}

\author{
Jacek Czubiński \\ e-mail: jacek.czubinski@wp.pl \\ Instytut Historii Architektury i Konserwacji Zabytków, Politechnika Krakowska
}

\begin{abstract}
Streszczenie: Kolegiacki kościół parafialny w Bieczu jest wybitnym przykładem architektury gotyckiej. W drugiej połowie XIX wieku przeprowadzono w nim prace restauracyjne, które w latach 1887-1895 nadzorował konserwator wiedeńskiej Centralnej Komisji Stanisław Tomkowicz. Praca prezentuje jego udział w konserwacji świątyni. Autorem projektu konserwatorskiego był Sławomir Odrzywolski. Przedstawiono wpływ Tomkowicza na decyzje projektowe oraz na zakres i sposób prowadzonych prac. Podjęto próbę określenia metody konserwatorskiej w relacji do panujących wtedy tendencji w ochronie zabytków, odejścia od tendencji restauracji stylowej na korzyść ścisłej konserwacji.
\end{abstract}

Słowa kluczowe: konserwacja zabytków, kolegiata w Bieczu, Sławomir Odrzywolski, Stanisław Tomkowicz, Stanisław Wyspiański

\section{Wprowadzenie i cel pracy}

W marcu 2018 roku mija 85 rocznica śmierci Stanisława Tomkowicza (1850-1933). Uważa się go za jednego z najbardziej znaczących polskich konserwatorów zabytków końca XIX i początku XX wieku. Ten germanista z wykształcenia, z zamiłowania historyk sztuki i kultury, aktywny członek wielu organizacji naukowych, autor ponad 650 artykułów i publikacji, od lat 80. XIX stulecia zajmował się głównie ochroną zabytków na terenie ówczesnej Galicji zachodniej. Przed I wojną światową sprawował szereg odpowiedzialnych funkcji z ramienia wiedeńskiej Centralnej Komisji konserwatorskiej, w tym konserwatora siedmiu powiatów Galicji zachodniej oraz konserwatora Krakowa i powiatu krakowskiego. Organizował, opiniował i nadzorował prace przy wielu ważnych obiektach na tym terenie, m.in. do lat 30. XX w. aktywnie uczestniczył w procesie restauracji zamku Królewskiego na Wawelu. Był istotnym współtwórcą zjawiska określanego jako krakowska szkoła konserwacji zabytków. Jednym z pierwszym obiektów, którym zajmował się instytucjonalnie w swojej karierze konserwatorskiej był kościół parafialny kościół kolegiacki (fara) Bożego Ciała w Bieczu. Można stwierdzić, że prace tam prowadzone kształtowały poglądy Tomkowicza na sposób konserwacji, zapoczątkowały odejście od metody stylowej restauracji historycznej w stronę nieinterwencjonizmu i „ścisłej” konserwacji. Pojawił się tam również istotny, a doktrynalnie nowy, problem wprowadzenia do konserwowanego obiektu sztuki współczesnej [Czubiński 1994].

Należy zauważyć, że o ile sam przebieg i zakres prac oraz uczestniczące w nich postaci zostały wyczerpująco opracowane [Ślawski 1982], to rola Tomkowicza w tym przedsięwzięciu nie została dotychczas wystarczająco określona. Artykuł ma na celu przybliżenie jego działalności związanej z tym obiektem w latach 1887-97 głównie w oparciu o korespondencje i dokumenty Grona Konserwatorów Galicji Zachodniej przechowywanych w archiwach krakowskich 1 . 


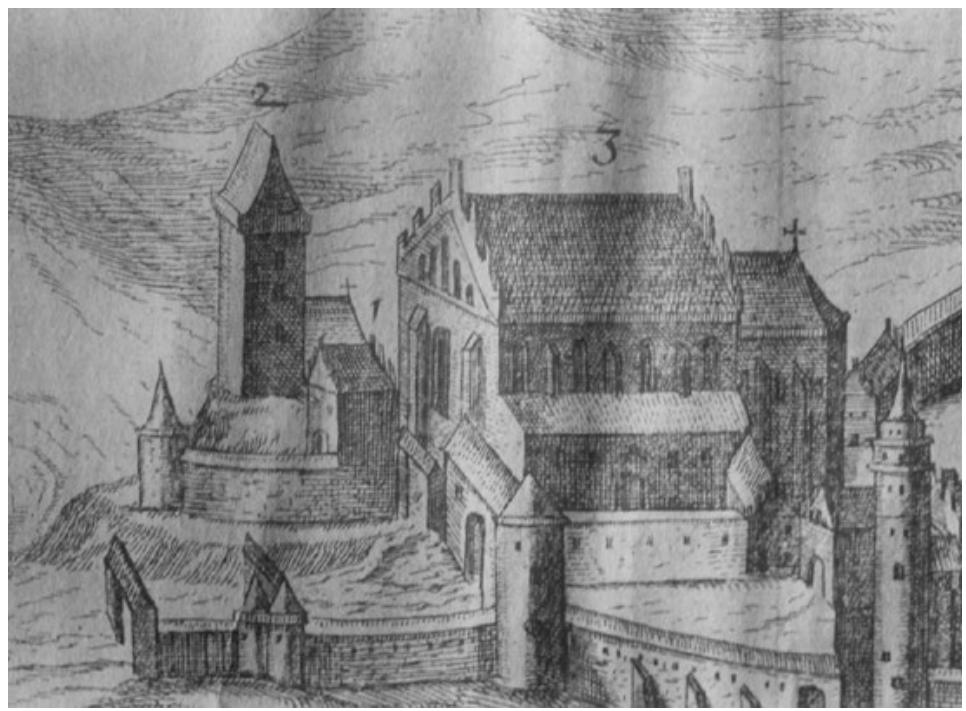

Ryc. 1. Kolegiata, około 1600 r. Fragment miedziorytu z: G. Braun, Civitate Orbis Terrarum 1605 r. Museum Narodowe w Krakowie (dalej MNK), sygn. MNK N.I. 71977. Collegiate church, around 1600. Fragment of an engraving: G. Braun, Civitate Orbis Terrarum 1605. National Museum in Kraków (further MNK), sygn. MNK N.I. 71977.

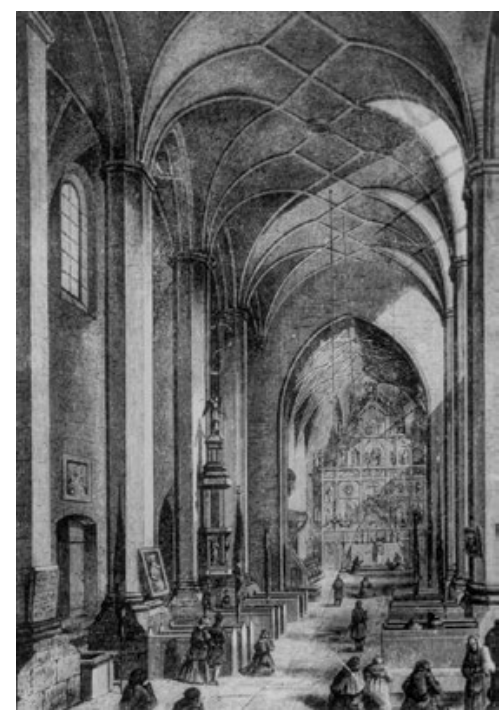

Ryc. 2. Wnętrze kolegiaty $z$ widokiem na prezbiterium. Rys. L. Piechaczek 1859 r. MNK III-ryc 27666.

Interior of the collegiate church. Drawing by L. Piechaczek 1859. MNK III-ryc 27666.

\section{Tomkowicz w Bieczu w roku 1887}

Kościół w Bieczu był wznoszony do końca XV w. a prezbiterium ukończono około roku 1520. Korpus główny posiada pięcioprzęsłową strukturę halową, trójnawową, z rzędem kaplic od północy i południa. Sklepienia sieciowe nawy głównej wsparte są na ośmiobocznych filarach. Czteroprzęsłowe prezbiterium zamknięte jest wielobocznie z zakrystią od północy. Kościół jest orientowany z głównym wejściem od zachodu. Posiada dwie kruchty między kaplicami w elewacjach północnej i południowej. Struktura ścian jest ceglana. We wnętrzu znajduje się szereg cennych elementów różnostylowego wyposażenia z XVI wiecznym ołtarzem głównym i stallami oraz wieloma nowożytnymi nagrobkami ściennymi i epitafiami.

Różnego rodzaju prace restauracyjne przy kościele prowadzono od lat 50. XIX w., zwłaszcza po przejęciu proboszczostwa bieckiego przez księdza Tomasza Jaszczóra w 1866 r. [Ślawski 1982; 46-48]. Prace nabrały tempa od 1871 roku, kiedy to Sejm Krajowy we Lwowie, na wcześniejszy wniosek Jaszczóra: poleca Wydziałowi Krajowemu aby zbadat potrzeby kościoła w Bieczu i przyszedt im w pomoc o tyle, ileby dzieła sztuki i pomnikowe wymagaty ${ }^{2}$. W tym okresie rejon ten podlegał opiece konserwatorskiej Karola Rogawskiego, który jako korespondent Centralnej Komisji konserwatorskiej we Wiedniu otrzymał polecenie od Józefa Łepkowskiego, będącego konserwatorem zabytków pomnikowych Galicji Zachodniej, zajęcia się problemami zabytków w Bieczu.

Rogawski zajmował się sprawami kościoła do marca roku 1887, kiedy to funkcję konserwatora tego rejonu powierzono Tomkowiczowi. Sprawował on tę funkcję do roku 1895, czyli do momentu objęcia stanowiska konserwatora miasta Krakowa i powiatu krakowskiego. Te dwie daty wyznaczają ramy czasowe bezpośredniego wpływu Tomkowicza na wszystkie prace prowadzone w kościele. Należy przy tym zauważyć, że również później, po formalnym przejęciu tego rejonu konserwatorskiego przez Tadeusza Stryjeńskiego, Tomkowicz w dalszym ciągu interesował się losami zabytku. Może o tym świadczyć fakt wyjazdu Tomkowicza do Biecza, wraz 
ze Stryjeńskim, w roku 1897 celem ustalenia zakresu dalszych prac. O wynikach tego wyjazdu Stryjeński zdał sprawozdanie na posiedzeniu Grona Konserwatorów Galicji Zachodniej w dniu 22.11.1897 r. ${ }^{3}$

Wydaje się, że jedną z pierwszych decyzji Tomkowicza było zaangażowanie odpowiedniego architekta posiadającego doświadczenie w restauracji zabytków. Zdecydował się na powierzenie tego zadania Sławomirowi Odrzywolskiemu. Wcześniej Łepkowski proponował Stryjeńskiego, jako członka Komitetu Restauracji Zabytków miasta Biecza. Rogawski optował za architektem Tomaszem Prylińskim pracującym wtedy przy restauracji katedry w Przemyślu. Nazwisko Odrzywolskiego pojawia się po raz pierwszy w związku z Bieczem w styczniu 1887 roku w korespondencji między nim a Rogawskim dotyczącej sporządzenia kosztorysu na remont dachu ${ }^{4}$. Daty pierwszych pism pochodzą jeszcze sprzed oficjalnego mianowania Tomkowicza konserwatorem Komisji Centralnej. Stąd wiadomo, że decyzja ta była wcześniej konsultowana przez Tomkowicza z Łepkowskim, który popierając i opiniując pozytywnie tę kandydaturę, uległ sugestiom Tomkowicza i zlecił to zadanie Odrzywolskiemu. Świadczy o tym list tego ostatniego do Tomkowicza w sprawie projektu i kosztorysu dla Biecza z datą 11 marca 1887 r., czyli z przed nominacji konserwatorskiej Tomkowicza, która nastąpiła formalnie 16 marca ${ }^{5}$.

Tomkowicz pojawił się pierwszy raz w Bieczu 30 stycznia 1887 r. Przyjechał tam wraz z Odrzywolskim na prośbę Rogawskiego, aby zapoznać się z zakresem czekających go w przyszłości zadań. Odrzywolski pracował nad projektem restauracji budynku, natomiast Tomkowicz miał przede wszystkim sporządzić kosztorys dotyczący konserwacji dzieł sztuki wewnątrz kościoła finansowanej przez subwencję sejmową . Argumentując konieczność przyznania takowej podkreślał: Kościót ten uważam nie tylko za najwspanialszą budowlę średniowieczną w moim okręgu konserwatorskim, ale za jeden z najważniejszych zabytków architektury w catym kraju naszym. Nadto wnętrze jego mieści nader wielka ilość cennych dziet malarstwa, rzeźby itd. z przeszłości, które czynia z kościoła tego jakby muzeum zabytków sztuki. Przejście gmachu tego w stronę ruiny byłoby więc niepowetowana klęska gdyż, pociagnętoby za sobą także zniszczenie prześlicznych ołtarzy, pomników, stall, ławek, obrazów, pamiatek historycznych, napisów itd. A ewentualność ta jest nieunikniona jeżeli się w najbliższej przyszłości do gruntownej naprawy dachu kościoła ${ }^{7}$.

\section{Zakres prac w latach 1887-1895}

Odrzywolski przedstawił projekt prac w kościele w marcu 1887 r. W pierwszym etapie robót przy prezbiterium, jeszcze w roku 1887, całkowicie wymieniono więźbę dachową pokrywając ją nową blachą miedzianą oraz wzmocniono spękane sklepienia. Podobnie musiano postąpić z dachem nawy głównej i kaplic. Wzmocniono także konstrukcję sygnaturki nad korpusem głównym. Duże problemy konstrukcyjne wystąpiły przy pracach wzmacniających statycznie ściany zewnętrzne budowli. W związku z planami budowy nowego chóru przy ścianie zachodniej nawy głównej, przebadano w 1895 r. stan techniczny kościoła. W wyniku tego wzmocniono posadowienie ścian zewnętrznych oraz filarów w nawie głównej. W roku 1895 zburzono i ponowne odtworzono niemal całości systemu sklepień w nawie głównej, nawach bocznych i kaplicach. Rok później uczyniono to samo w prezbiterium ${ }^{8}$.

Istotnym przedsięwzięciem w duchu stylowej konserwacji historycznej był projekt restauracji dzwonnicy przykościelnej ${ }^{9}$. Wieża ta była pierwotnie obronną basztą w obwodzie murów miejskich Biecza, później zamienioną na dzwonnicę. Zwieńczono ją w XVII wieku krytym gontem hełmem z latarnią. Osłabienie ścian konstrukcyjnych

3 [Teka 1900: 450]. Wyjazd miał miejsce po śmierci w 1897 r. księdza Ziemiańskiego, następcy, zmarłego w 1887 r., księdza Jaszczóra na stanowisku proboszcza w Bieczu. Grono Konserwatorów przywiązywało wielką wagę do prawidłowej opieki nad tym obiektem. Świadczyć o tym może pismo skierowane przez Grono, po śmierci Ziemiańskiego, do biskupa przemyskiego Łukasza Soleckiego z prośbą: by nowy proboszcz był miłośnikiem sztuki. Proboszczem został ksiądz Leon Pastor; por.: list Grona Konserwatorów Galicji Zachodniej do księdza biskupa Łukasza Soleckiego z dnia 24.07.1897 r.; APKr, GK-14.

4 Pierwsze listy Odrzywolskiego do Rogawskiego, zachowane w materiałach Grona Konserwatorów, noszą daty: 23.01 .87 i 27.01 .87 r.; APKr sygn.: GK-6.

5 Akt nominacyjny Tomkowicza na konserwatora Komisji Centralnej; MNK-B.Cz., sygn.: MNK, 609 VII R, 4680.

6 Pismo Rogawskiego do Łepkowskiego z dnia 31.03.87 r.; MNK-B.Cz.; sygn.: MNK 609, VIII R, 4680.

7 Petycja do Sejmu Krajowego sporządzona przez Tomkowicza z dnia 25.11.87 r. o subwencję na restaurację kościoła w Bieczu, brudnopis MNK-B.Cz.; sygn.: MNK 609, III R, 4680.

8 Sprawozdanie ks. Ziemińskiego z restauracji kościoła parafialnego w Bieczu, maszynopis z datą 16.01.1897 r.; APKr.; sygn. GR 14.

9 Projekt przechowywany jest w Gabinecie Rycin MNK; sygn.: Biecz-fara; MNK III PI. 5. 
wieży spowodowało konieczność jej restauracji wraz z utrwaleniem dekoracji sgraffitowej. Projekt Odrzywolskiego z 1887 r. przewidywał pozostawienie elewacji bez większych zmian, z zastąpieniem barokowego hełmu innym inspirowanym najprawdopodobniej przez widok tej baszty na szesnastowiecznym sztychu Brauna przedstawiającym panoramę miasta. Widnieje na nim dwuspadowy dach kalenicowy kryty dachówką z lekkim nachyleniem połaci bocznych. Ta forma zwieńczenia wieży: wiele mogłaby się przyczynić do podniesienia widoku catości $i^{10}$. Koncepcja ta została odrzucona przez Tomkowicza, który nie zgadzał się na zmianę istniejącej sylwety tej części miasta.

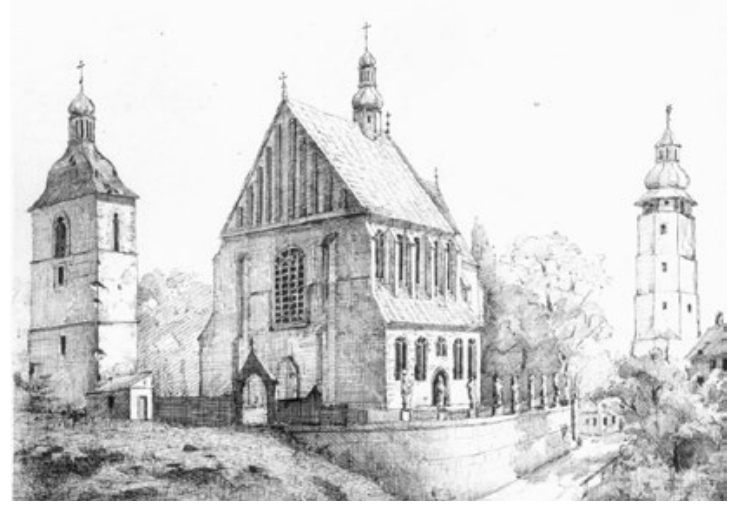

Ryc. 3. Widok kolegiaty od płd.-zach. Rysunek A. Kotowicza, około 1883 r. MNK III-ryc 27665.

Collegiate church from south-west. Drawing by A. Kotowicz, around 1883. MNK III-ryc 27665.

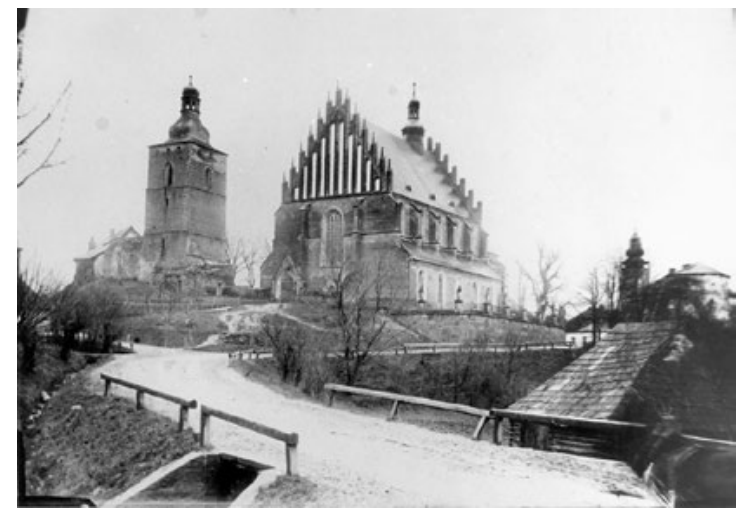

Ryc. 4. Widok kolegiaty od płd.-zach. Fot. I. Krieger, około 1895 r. Reprodukcja w zbiorach prywatnych.

Collegiate church from south-west. Photo by I. Krieger, around 1895. Private collection.

Ważnym przejawem tendencji rekonstrukcyjnej było odtworzenie pierwotnych kształtów obydwóch, zachodniego i wschodniego, szczytów kościoła. Koniec wieku XIX zastał je bez charakterystycznych gotyckich szczytów schodkowych z pinaklami. Zdecydowano się przywrócić pierwotny wygląd zewnętrzny bryły kościoła poprzez rekonstrukcję tych elementów. Wzorem dla tej rekonstrukcji były najprawdopodobniej pochodzące z XVII w. ryciny z widokami miasta. Kształt i profile fial odtworzono przez analogię do tychże ze szczytów kościoła Bożego Ciała i Collegium Maius w Krakowie [Frazikowa 1974; 62].

Podczas usuwania zniszczonego tynku na elewacjach prezbiterium odkryto pod nim gotycki układ wątku ceglanego z romboidalnym wzorem zandrówkowym. Zdecydowano się na jego całkowite odsłonięcie, uzupełniając miejscami zatarte jego fragmenty. W trakcie prac przy elewacjach wymieniono zniszczone kamienne okładziny szkarp. Zastąpiono także ceglany gzyms podokapowego nowym kamiennym, zachowując przy tym ich oryginalny profil. Wszystkie okna korpusu głównego, prezbiterium oraz zakrystii i kaplicy ponad nią otrzymały nową kamieniarkę ościeżnic i parapetów. W kilku oknach naw bocznych oraz w oknie elewacji zachodniej wymieniono na nowe kamienne laskowania. Starano się przy tym zachować pierwotne profile i kompozycję maswerków. W prezbiterium odtworzono przy tym dwa zamurowane wtórnie okna od wschodu.

Wyraźną tendencją w koncepcji restauracji wnętrza była chęć jego ujednolicenia stylowego. Temu celowi służyć miały działania zmierzające do odsłonięcia jego kamiennej struktury. Usunięto stary tynk pokrywający ściany i sklepienia. W miejscach, gdzie pokazał się kamienny wątek był on odczyszczany oraz wymieniono wiele zniszczonych ciosów. Natomiast tam, gdzie mieszał się on z wątkiem ceglanym, cegłę zastępowano ciosami kamiennymi. Roboty te skoncentrowały się głównie na filarach nawy głównej. Wykonano także nowa okładzinę kamienną na łuku tęczowym oraz gzyms kamienny na wewnętrznej ścianie prezbiterium gdzie zastąpiono cegłę profilowanymi ciosami kamiennymi. Temu samemu celowi służyć miały inne elementy, projektowane w formach neogotyckich. Przykładem może być nowy portal wejściowy ze schodami w elewacji zachodniej, w którym wymieniono zniszczone ościeżnice kamienne zmieniając przy tym ich profilowanie.

Regotyzacja dotyczyła głównie struktury architektonicznej budynku, nie rozciągając się na jego zabytkowe wyposażenie. Nowym elementem wprowadzonym do wnętrza był chór muzyczny projektu Odrzywolskiego nad 
zachodnim wejściem głównym. Umieszczono go na miejscu rozebranego starego, z częściowym wykorzystaniem oryginalnych detali. Zaprojektowany w historycznych formach, wraz z nowym prospektem organowym stanowić miał istotny element kompozycyjny dopełniający wielostylowy wystrój wnętrza.

Konserwując dzieła sztuki będące wyposażeniem kościoła Tomkowicz zlecał to zadanie sprawdzonym rzemieślnikom. Drobne przedmioty były wysyłane do Krakowa. Przykładowo rzemieślnik Józef Maria Brzostowski otrzymał zadanie restauracji dwóch metalowych lichtarzy gotyckich w końcu roku 188911. Obraz z ołtarza głównego restaurował w Monachium konserwator Aloizy Hauser. Warto przytoczyć opinię ówczesnego proboszcza księdza Stanisława Ziemiańskiego o efekcie jego pracy: Cały (obraz) przeniesiony na nowe, mocne płótno - kolory świeże, twarze pojedynczych osób wybitne itp. Tylko Magdalena nie ma już tego cudnego koloru włosów, jaki byt przed restauracja obrazu ${ }^{12}$. Natomiast zadanie konserwacji samego głównego ołtarza, dwóch zestawów stall w prezbiterium, ławek z intarsjami oraz ambony otrzymał kolejny krakowski rzemieślnik K. Wokulski, który prace te wykonywał na miejscu w Bieczu ${ }^{13}$.

\section{Projekt nowej polichromii}

Kontrowersyjnym, do dzisiaj aktualnym zagadnieniem jest stosunek konserwatorów zabytków do sztuki nowoczesnej i współistnienie jej z substancją zabytkową.

Decyzje i wybory podejmowane w tym zakresie są zwykle bardzo trudne i często opierają się na osobistych upodobaniach konserwatorów, a nie na wypracowanej i przemyślanej teorii estetycznej. Sztuka współczesna konserwatorowi zabytków, pozbawiona bezpiecznego dystansu czasowego wymyka się wartościującej ocenie i często może powodować dysonans z wartościami artystyczno-historycznymi dzieła sztuki. Na okres działalności konserwatorskiej Tomkowicza przypadły dwa poważne przełomy artystyczne. Pojawiła się symboliczna sztuka młodopolska w końcu XIX wieku, a później wielość nurtów sztuki awangardowej lat

20-tych o tendencjach ekspresjonistycznych i abstrakcyjnych. Naturalna i zrozumiała była ostrożność, a nawet nieufność Tomkowicza przy wprowadzaniu nowoczesnej wówczas sztuki do obiektu zabytkowego. Widać to zwłaszcza w wypadku projektów artystów z przełomu wieków w tym Stanisława Wyspiańskiego.

Całość prac w kościele sprowadzała się do utrwalenia i podkreślenia gotyckich cech architektury budynku, była to więc restauracja historyczna. Wszelkie nowe elementy wprowadzane do wnętrza i zmiany na elewacjach dostosowane były stylistycznie do form średniowiecznych. Podobnie rzecz wyglądała z wystrojem i dekoracją wnętrza. Tylko w jednym przypadku możemy mówić o odstępstwie od tej zasady.

Pojawiła się szansa wprowadzenia do kościoła dzieła sztuki o nowatorskiej na tamte czasy stylistyce. Chodzi o niezrealizowaną polichromię wnętrza i witraże projektu Stanisława Wyspiańskiego. Wyspiański otrzymał tę propozycję od Odrzywolskiego w październiku 1895 r. i pracował nad nią do końca roku następnego. Niestety, architekt nie był usatysfakcjonowany projektem i po nieudanych próbach wpłynięcia na artystę, aby dokonał w nim szeregu zmian, zrezygnował z jego usług. Odrzywolski próbował narzucić Wyspiańskiemu zupełnie inną stylistykę kompozycji, nalegał na odejście od form młodopolskich. Należy sądzić, że pragnął widzieć tę dekorację malarską utrzymaną w stylistyce historycznej. Wyspiański tworzył ją w duchu symboliczno-wizyjnym. Odrzywolski zaś spodziewał się realizmu i przedstawień czysto religijnych [Płoszewski L., Rydlowa M.1979: 324-327; także Puciata-Pawłowska 1979: 105-117]. Wyspiański w ten sposób charakteryzuje postawę Odrzywolskiego po niemal ostatecznej już utracie zlecenia na wykonanie polichromii: Biecz się psuje, prawie że przepada, bo Odrzywolski stanowczo obstaje za książka i żąda ode mnie, abym wyzbywszy się "naturalizmu" (!) wziąt dzieła takie i owakie i zrobit kompilację. W trakcie wielomiesięcznej pracy nad projektem zarzucił architektowi konserwatyzm myślenia i zupełne niezrozumienie nowych tendencji w sztuce. Wyspiański zajmował się także projektem, również niezrealizowanym, witraży do tego kościoła. Niestety niewiele wiadomo o szczegółach tej pracy. Jedynym tego dowodem jest karton, na podstawie którego wykonano witraż prezentowany w $1929 \mathrm{r}$.

11 Prace te były finansowane przez Tomkowicza z jego własnych funduszy. Potwierdzenia otrzymania zaliczek na konto restauracji lichtarzy wystawione przez J. M. Brzostowskiego z datami: 25.10.88, 12.11.88, 07.01.89 oraz 12.02.89; MNK-BC: sygn.. MNK VIII R 609, 4680.

12 List ks. Ziemiańskiego do Tomkowicza z dn. 30.12 .89 r.; MNK-BC: sygn.. MNK VIII R 609, 4680.

13 Umowa na wykonanie wymienionych prac zawarta w dniu 7.05.1889 r. między Wokulskim a Tomkowiczem; MNK-BC: sygn.. MNK VIII R 609, 4680. 
na Powszechnej Wystawie Krajowej w Poznaniu, umieszczony później w kaplicy w katedrze w Katowicach. Nie wykluczonym jest, iż istnieje ślad działalności Wyspiańskiego zachowany w kościele w Bieczu. Mogły by nim być kwiatowe kompozycje witraży okien kaplic południowych [Ślawski 1982: 53].

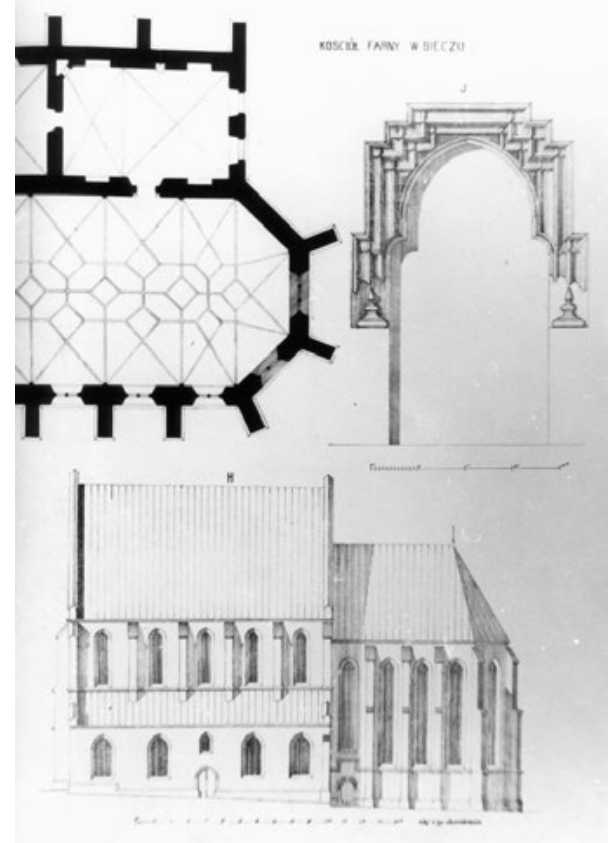

Ryc. 5. Fragment inwentaryzacji architektonicznej kolegiaty. W. Łuszczkiewicz, około 1866 r. Reprodukcja w zbiorach prywatnych.

Fragment of measuring drawings of collegiate church. W. Łuszczkiewicz, around 1866 r. Reproduction in private collection.

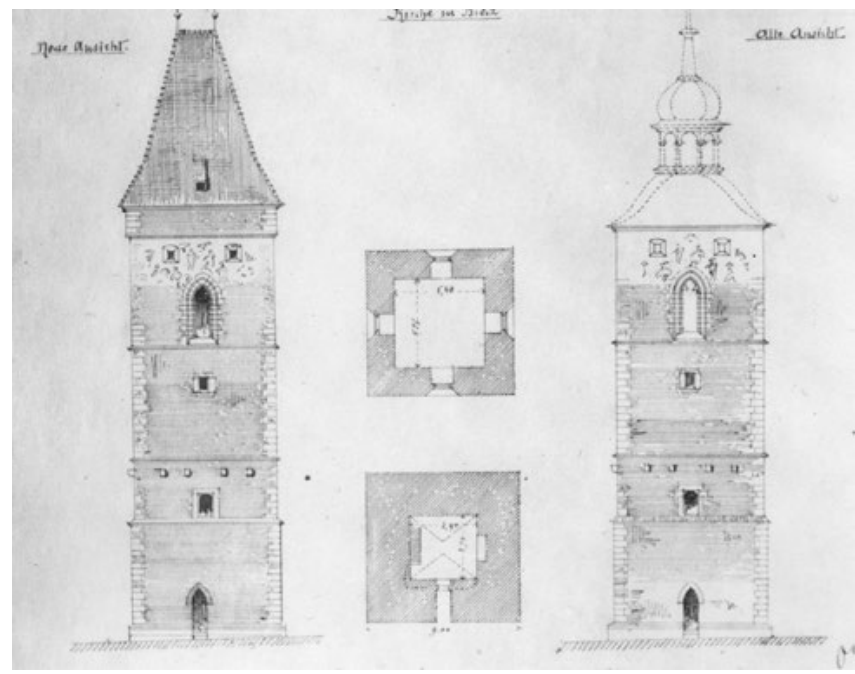

Ryc. 6. Projekt restauracji dzwonnicy. S. Odrzywolski 1887. MNK III-PI 5. Belfry restoration design. S. Odrzywolski 1887. MNK III-PI 5.

Po odrzuceniu projektów Wyspiańskiego, mimo przygotowania tynkowej wyprawy pod polichromie ścian i sklepień, kościół pozbawiony był dekoracji malarskiej aż do roku 1905, kiedy to wykonał ją Włodzimierz Tetmajer.

Należy spróbować określić stanowisko Tomkowicza w tej sprawie. Nie mamy niestety bezpośrednich świadectw jego udziału w podjęciu decyzji o odrzuceniu projektu Wyspiańskiego. Wiemy natomiast, że nie darzył w tym czasie zbytnią sympatią samego Wyspiańskiego i jego sztuki. Płoszewski z Rydlową twierdzą: Tomkowicz nie był przychylny Wyspiańskiemu, nigdy nie umiał należycie ocenić jego dziet [Płoszewski L., Rydlowa M.1979: 187]. Jest więc niemal pewnym że Tomkowicz wpłynął na ostateczną decyzję Odrzywolskiego. Widział potrzebę uzupełnienia wnętrza polichromią, lecz chciałby, by była ona jednolicie zharmonizowana z charakterem gotyckiego wnętrza, czyli operowała formami historycznymi. Nie dopuszczał w zabytkowych wnętrzach eksperymentów formalnych, jakim bez wątpienia była na owe czasy sztuka młodopolska, zwłaszcza w symbolicznym wydaniu Wyspiańskiego. Dowodem na to może być także fakt, iż Wyspiański ubolewa w jednym z listów do Rydla, że nie może znaleźć poparcia dla własnej sztuki wśród znaczących osób z Krakowa. Twierdzi w nim z pełnym przekonaniem: ani myśle abym ja na krakowskim gruncie znalazł człowieka co by mnie popart dla moich planów i pomysłów i pracy, to mi się w głowie nie mieści. Jednocześnie wypowiada znamienne dla jego twórczości słowa: Bądź przekonany, że przeciwności zaostrzają tylko mój apetyt do rozwoju, do rozwoju niezależności własnej, z którą mam zamiar maszerować wysoko ponad głowami Ekielskich i Odrzywolskich [Płoszewski L., Rydlowa M.1979: 327]. Opinia Wyspianskiego nie wydaje się w pełni obiektywna. W 1895 r. rozpoczął on bowiem prace, przy poparciu Ekielskiego, nad dekoracją ścienną do kościoła Franciszkanów, a na jesieni roku 1896 otrzymał od Stryjeńskiego częściowe zlecenie przy odsłonięciu i rejestracji polichromii w kościele św. Krzyża [Borowiejska-Birkenmajerowa 1991: 106, 111-112]. 


\section{Postawa Stanisława Tomkowicza}

Tomkowicz był w tym czasie zdecydowanym zwolennikiem restauracji stylowej, jednak tylko w stosunku do samej struktury architektonicznej kościoła. Dopuszczał, wręcz propagował odtworzenia i rekonstrukcje detali nadających całości gotycki charakter. Argumentował w ten sposób: Dodatki projektowane przez architekta, jak zazębienie szczytów kościelnych, naprawa pięknej sgraffitami zdobionej dzwonnicy itp. sa tylko koniecznym przywróceniem szczegótów potrzebnych do artystycznej całości, szczegótów, które były niegdys ${ }^{4}$. W korespondencji z władzami zawsze podkreślał konieczność uzupełnień i dopełnień nadających jednolity obraz całości kompozycji. Temu miały służyć uzupełnienia szczytów i odsłonięcie gotyckiej struktury ceglanych ścian.

Jedynym, acz zdecydowanym i znaczącym odejściem od tej zasady było, po wstępnym zaakceptowaniu, odrzucenie pomysłu kreacji średniowiecznego zwieńczenia dzwonnicy kosztem likwidacji barokowego hełmu. Nastąpiło to, jak się wydaje, na skutek powolnej ewolucji poglądów Tomkowicza na samą zasadę restauracji stylowej. Stopniowo bowiem stawał się wyznawcą teorii ochrony zastanej zabytkowej substancji, w tym sylwety zespołu, nawet gdy nie był on jednorodny formalnie.

Natomiast jeżeli chodzi o wnętrze, zgadzając się na podkreślenie jego średniowiecznego wyglądu poprzez odpowiednie architektoniczne uzupełnienia, z całą stanowczością wysuwał postulaty pozostawienia i konserwacje wszystkich jego elementów wyposażenia pochodzących z różnych epok stylowych. Najlepiej o tym mogą świadczyć wysiłki jakie podejmował, nie szczędząc nawet swoich prywatnych funduszy, aby doprowadzić do właściwego zabezpieczenia i niezbędnej konserwacji zachowanych w nim cennych zabytków.

W owym okresie Tomkowicz nie był przychylnie nastawiony do nowej sztuki modernistycznej. Doceniał wprawdzie talent i wyobraźnie twórców, lecz nie potrafił zrozumieć istoty tej stylistyki i nowego typu wrażliwości artystów. W recenzji z wystawy "Sztuki" w 1897 r. pisał z ironią o "panach secesjonistach". Wyspiańskiemu poświęcił taki passus: Na wskroś dekadentem wydaje mi się być inny młody malarz, Wyspiański. Talent niezaprzeczony, majacy wysokie poczucie stylu. Jego stylizowane rośliny polskich pól, użyte jako motywa dekoracyjne do ścian kościoła OO Franciszkanów w Krakowie i do projektu dekoracji kościoła w Bieczu, sa arcydzietem w swoim rodzaju. Ale cóż kiedy styl u artysty staje się manierą. Szuka on zawsze czegoś nadzwyczajnego, stara się być innym niż wszyscy i chcą być oryginalnym, staje się dziwacznym. (...) Pan Wyspiański wszystko czyni, aby być niezrozumiatym, zdaje się z upodobaniem szukać brzydoty dla brzydoty, a bez powodu i bez celu lubuje się bodaj czasem w rażących btędach rysunkowych [Tomkowicz 1897]. Trudno zatem się spodziewać, aby wyrażając takie poglądy popierał udział Wyspiańskiego w dekorowaniu wnętrz kościoła w Bieczu.

Jednak stosunek ten bardzo szybko uległ zmianie i Tomkowicz wkrótce zaakceptował, wprawdzie z pewnymi zastrzeżeniami, nową estetykę. Przekonał się także do twórczości Wyspiańskiego. Już bowiem w roku 1900, czyli w niespełna w trzy lata po wspomnianym artykule w Czasie", analizując witraże Wyspiańskiego do kościoła OO Franciszkanów w ten sposób o nich i ich twórcy pisze: Pan Wyspiański, (...) jest na wskróś modernista, a przy tym talentem nadzwyczaj oryginalnym. (...) Można to lubić lub nie, można krytykować i wyszukiwać niedostatki lub usterki przeciw przyjętym prawidłom. W każdym razie jest w tym niepospolita siła twórczości, talent dekoracyjny, śmiałość pomystów i zamach rysunkowy. (...) Kraków jest bodaj pierwszym miastem, w którym sprowadzono modernizm do witraży kościelnych. Próba wypadła zajmująco, choć wolelibyśmy, aby takie doświadczeni odbywały się w kościołach nowych, a nie w zabytkach architektury średniowiecznej [Tomkowicz 1900: 78-79]. Widać w powyższym tekście pewną dumę z udanego przedsięwzięcia artystycznego. Jedyną wątpliwością jest obawa co do stosowności wprowadzania sztuki nowej do wybitnych dzieł historycznej architektury. Także i ta niepewność szybko zostanie przezwyciężona we wnętrzach restaurowanej katedry wawelskiej.

\section{Podsumowanie}

Stanisław Tomkowicz jako konserwator wiedeńskiej Centralnej Komisji oraz oficjalny konserwator IV okręgu, na terenie którego położony był Biecz, miał bardzo istotny wpływ na sposób, zakres i realizację prowadzonych prac konserwatorskich. Podstawowym jego zadaniem było określenie ich metody w relacji do istniejących tendencji

14 Opinia Tomkowicza o projekcie Odrzywolskiego z dnia 25.11 .87 przesłana w formie petycji do Sejmu Krajowego o subwencję państwową, na restauracje kościoła w Bieczu, brudnopis; MNK-B.Cz.; sygn.: MNK 609, VIII R, 4680. 
w ochronie zabytków. W tym wypadku widzimy początki odejścia od starej tendencji restauracji stylowej na korzyść ścisłej konserwacji. Współdecydował o wyborze Odrzywolskiego na architekta, uzgadniał rozwiązania projektowe i zakres interwencji. To on najprawdopodobniej zdecydował o odrzuceniu projektu polichromii zaproponowanego przez Wyspiańskiego. Do jego obowiązków należała także szeroko rozumiana organizacja prac. Proponował wykonawców nadzorował jakość ich pracy oraz koordynował wspólnie z projektantem prowadzone roboty. Zajmował się także organizacją finasowania prac, osobiście pokrył koszty konserwacji lichtarzy. Występował do różnych instytucji o subwencję, opiniował i ostatecznie aprobował kosztorysy, negocjował ceny i rozliczał wydawane fundusze.

\title{
Literatura
}

[1] Borowiejska-Birkenmajerowa M. 1991: Serce Polski, zabytki i świadomość narodowa, Kraków.

[2] Czubiński J. 1993: Wpływ Stanisława Tomkowicza na polską teorie i praktykę konserwacji zabytków, niepublikowana praca doktorska wykonana w roku 1994 w Instytucie Historii Architektury i Konserwacji Zabytków Politechniki Krakowskiej pod kierunkiem prof. dr hab. inż. arch. Andrzeja Kadłuczki. Maszynopis w Bibliotece PK, t. I, II.

[3] Frazikowa R. 1974: Architektura późnogotyckiej fary w Bieczu, Rocznik Województwa Rzeszowskiego, Rzeszów, t. III,.

[4] Płoszewski L., Rydlowa M. (oprac.) 1979: Listy Stanisława Wyspiańskiego do Lucjana Rydla, Kraków, t. II, cz. 1 i 2.

[5] Puciata-Pawłowska J. 1979: Opieka nad "Pamiątkami Przeszłości" w świetle wypowiedzi Stanisława Wyspiańskiego, Zabytkoznawstwo i konserwatorstwo, Toruń, z. 91.

[6] Ślawski T. 1969: Stanisława Wyspiańskiego kontakty z Bieczem, Rzeszów.

[7] Ślawski T. 1982: Z zagadnień konserwatorskich Biecza i najbliższych okolicy, Teka Konserwatorska. Polska południowo-zachodnia, Rzeszów.

[8] Teka Grona Konserwatorów Galicji Zachodniej 1900: Kraków.

[9] Tomkowicz S. 1897: Wystawa obrazów w Sukiennicach, „Czas”, Kraków, nr 128, 131, 133 z 6.

[10] Tomkowicz S. 1900: w: Kronika Krakowska, Józefa Czecha Kalendarz Krakowski na rok 1900, Kraków.

\section{Participation of Stanisław Tomkowicz in the conservation of the Corpus Christi collegiate church in Biecz}

\begin{abstract}
The collegiate parish church in Biecz is an outstanding example of Gothic architecture. In the second half of the nineteenth century, he carried out restoration work, what in 1887-1895 was supervised by the conservator of the Vienna Central Commission, Stanisław Tomkowicz. The article presents his participation in the preservation of the church. Sławomir Odrzywolski was the author of the conservation project. Tomkowicz's influence on design decisions as well as the scope and manner of conducted works was presented. An attempt was made to determine the conservation method in relation to prevailing tendencies in protection of monuments, moving away from the trend of a stylistic restauration in favor of strict conservation.
\end{abstract}

Key words: conservation of monuments, collegiate parish church in Biecz, Sławomir Odrzywolski, Stanisław Tomkowicz, Stanisław Wyspiański 